
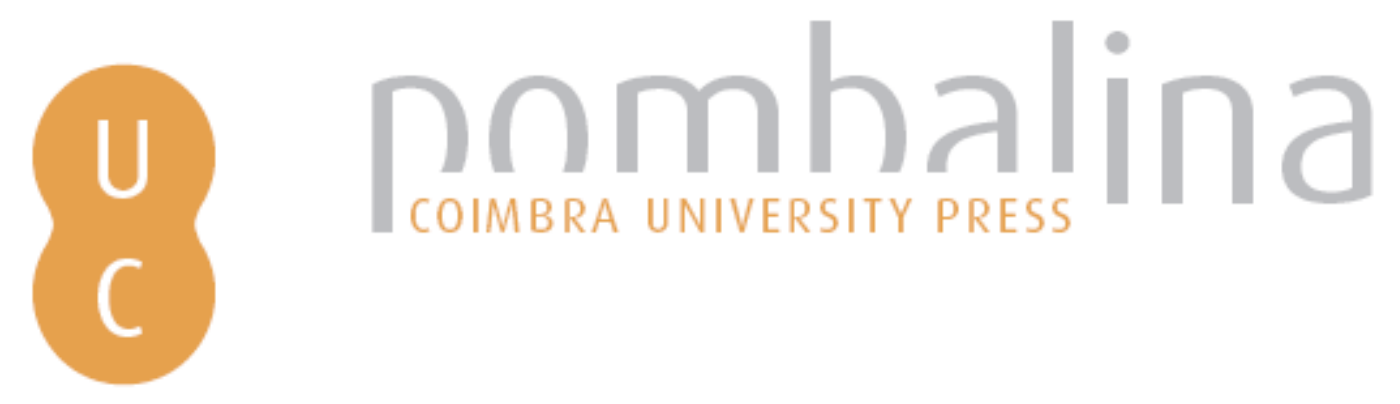

\title{
Flammability and combustibility of potential species for use as fuel breaks
}

$\begin{array}{ll}\text { Autor(es): } & \text { Santos, João Francisco Labres dos; Batista, Antonio Carlos; Tres, } \\ \text { Andressa; Tetto, Alexandre França; Kovalsyki, Bruna }\end{array}$

Publicado por: Imprensa da Universidade de Coimbra

URL

persistente: URI:http://hdl.handle.net/10316.2/44603

DOI: $\quad$ DOI:https://doi.org/10.14195/978-989-26-16-506_86

Accessed : $\quad$ 26-Apr-2023 12:39:00

A navegação consulta e descarregamento dos títulos inseridos nas Bibliotecas Digitais UC Digitalis, UC Pombalina e UC Impactum, pressupõem a aceitação plena e sem reservas dos Termos e Condições de Uso destas Bibliotecas Digitais, disponíveis em https://digitalis.uc.pt/pt-pt/termos.

Conforme exposto nos referidos Termos e Condições de Uso, o descarregamento de títulos de acesso restrito requer uma licença válida de autorização devendo o utilizador aceder ao(s) documento(s) a partir de um endereço de IP da instituição detentora da supramencionada licença.

Ao utilizador é apenas permitido o descarregamento para uso pessoal, pelo que o emprego do(s) título(s) descarregado(s) para outro fim, designadamente comercial, carece de autorização do respetivo autor ou editor da obra.

Na medida em que todas as obras da UC Digitalis se encontram protegidas pelo Código do Direito de Autor e Direitos Conexos e demais legislação aplicável, toda a cópia, parcial ou total, deste documento, nos casos em que é legalmente admitida, deverá conter ou fazer-se acompanhar por este aviso.

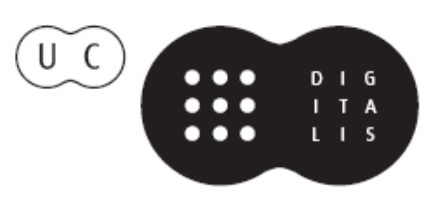




\section{ADVANCES IN}

\section{FOREST FIRE RESEARCH}

\section{8}

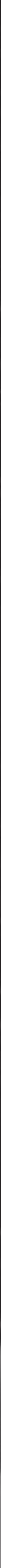




\title{
Flammability and combustibility of potential species for use as fuel breaks
}

\author{
João Francisco Labres dos Santos*; Antonio Carlos Batista; Andressa Tres; Alexandre França \\ Tetto; Bruna Kovalsyki \\ Federal University of Paraná. Av. Lothário Meissner, 632, 80210-170, Curitiba, Paraná, Brazil, \\ \{joaolabres@ufpr.br*,batistaufpr@ufpr.br,tres.andressa@gmail.com,tetto@ufpr.br, \\ kovalsyki@ufpr.br\}
}

\begin{abstract}
In order to minimize the incidence and magnitude of fires, preventive silviculture proposes the establishment of fuel breaks, which is strips of vegetation with species of lower flammability than those of the main cultivation, with the aim of reducing or avoiding fire spread. The objective of the study was to evaluate the flammability and combustibility of eight ornamental species by means of cluster analysis, and indicate their potential for use as fuel breaks. Flammability was determined according to the methodology recommended by Valette (1990) and Petriccione (2006). For each evaluated species, 50 firing repetitions were performed in the epirradiator, each one consisting of $1 \pm 0.1 \mathrm{~g}$ of fine green combustible material $(\varnothing<$ $0.7 \mathrm{~cm}$ ). In the tests the following combustion characteristics were analyzed: Ignition Time (IT), Ignition Frequency (IF), Duration of Combustion (DC) and Flame Height (FH). The fire behavior components were measured according to the methodology presented by Batista and Biondi (2009). The experimental burns were carried out in $1 \mathrm{~m}^{2}(1 \mathrm{~m} \mathrm{x} 1 \mathrm{~m})$ plots, with a load of $1 \mathrm{~kg} . \mathrm{m}^{2}$ for all treatments. The following parameters were analyzed: Flame Height (FHh), Speed of Propagation (SP) and Residual Material (RM). The Lower Calorific Value (LCV) was determined with an isoperibol calorimeter, following the standard of ABNT NBR 8633/1984 and was expressed by calories per gram (kcal.kg-1). The Flammability Value (FV) was obtained according to the methodology applied by Vallete (1990) and the fire intensity was estimated using the Byram equation (1959). The parameters IF, IT, DC and FH of flammability and FHh, SP, RM and LCV of combustibility were submitted to cluster analysis. Schinus terebinthifolius and Bougainvillea glabra were the species that presented the lowest values of flammability and combustibility being classified in the null class, as well as Rhododendron simsii in the low classification class. Jasminum mesnyi has low combustibility, but high flammability, not being indicated for composing a fuel break. Viburnum odoratissimum showed low ignition capacity, but its combustibility presented superior parameters when compared to Pinus taeda. Magnolia grandiflora, even with some inferior parameters than those of $P$. taeda, has the lowest IT, being highly flammable and not recommended for use in fuel breaks. $S$. terebinthfolius, B. glabra and $R$. simsii are the species indicated for use as fuel breaks.
\end{abstract}

Keywords: forest fires, preventive silviculture, calorimetry, combustible material.

\section{Introduction}

Natural disturbances are important for ecosystems functioning and, under normal conditions in healthy ecosystems, are an intrinsic part of nature. However, catastrophic events can seriously affect environmental functions and human activities (Montagné-Huck and Brunette 2018).

Forest fires at the Wildland-Urban Interface (WUI) are a threat to communities in many countries (Mell et al. 2010) and a growing problem with social and economic impacts (Molina et al. 2017).

The main cause of forest fires at WUI is anthropogenic (Long-Fournel et al. 2013). A lack of awareness of the risk of forest fires is observed, since residents generally tend to underestimate it (Meldrum et al. 2015). The high population density and the negligent attitude of people who inhabit or transit these regions (Castillo et al. 2011), combined with long periods of drought and accumulation 
of combustible material (Mell et al., 2010), increase the risk of ignition. In this context, it is possible to mention the recent events in Pedrógão Grande/Portugal (2017), Tathra/Australia (2018), New Mexico and Colorado/United States (2018).

Thus, land use planning should be considered as an important component of fire risk management (Syphard et al. 2013). In view of the vulnerability of WUI to forest fires, due to the risk to human life and damage to residences (Long-Fournel et al. 2013), vegetation around homes becomes a major concern as it can facilitate the reach of fire in these structures (Castillo and Correa 2012; Ganteaume et al. 2013).

One method to mitigate the probability of homes being damaged by fire is to reduce the flammability of surrounding areas (Molina et al. 2017). In this context, preventive silviculture proposes the establishment of fuel breaks, which is strips of vegetation with species of lower flammability and combustibility than those of the main cultivation, in order to reduce or prevent the fire spread (Haltenhoff 2006).

To determinate the species to compose fuel breaks, it is evaluated: i) flammability, which is the capacity of the vegetation to burn; and ii) combustibility, which characterizes the ability of the combustible material to maintain the combustion process and to propagate the fire (Soares et al. 2017). Thus, the objective of the study was to evaluate the flammability and combustibility of eight ornamental species, by means of cluster analysis, and indicate their potential for use as fuel breaks.

\section{Material and methods}

The flammability and combustibility tests were carried out in the Forest Fire Laboratory of the Federal University of Paraná, Brazil.

Nine potential species were selected for use as fuel breaks: Bougainvillea glabra Choisy., Casearia sylvestris Sw., Jasminum mesnyi Hance., Magnolia grandiflora L., Michelia champaca L., Rhododendron simsii Planch., Schinus terebinthifolius Raddi and Viburnum odoratissimum Ker Gral. Pinus taeda L. was used as control of the experiment because it is a species of high economic interest.

\subsection{Flammability test}

Flammability was determined according to the methodology recommended by Valette (1990) and Petriccione (2006). For each evaluated species, 50 firing repetitions were performed in the epirradiator, each one consisting of $1 \pm 0.1 \mathrm{~g}$ of fine green combustible material $(<0.7 \mathrm{~cm}$ in diameter) (Figure 1).
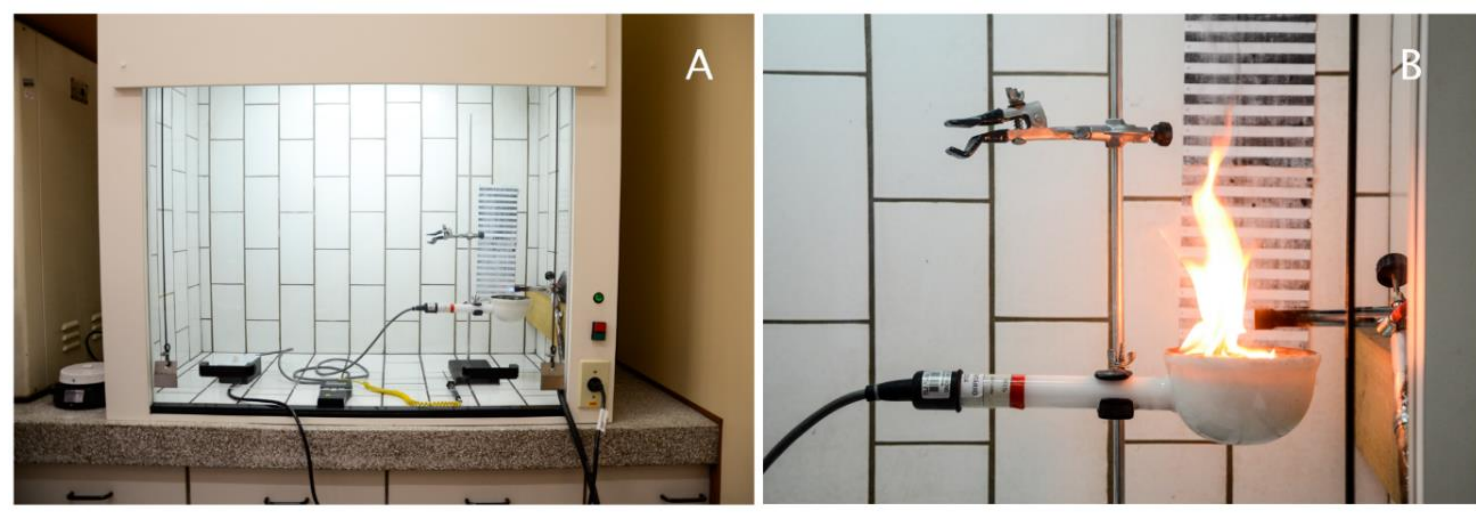

Figure 1 - Epirradiator in the fume hood (A) and epirradiador test (B)

In the tests, the following combustion characteristics were analyzed: ignition time (IT), in seconds, time of complete combustion (TC), in seconds, maximum flame height (FH), in centimeters and ignition frequency (IF), in percentage. IF is the percentage of repetitions in which ignition occurred, considering a maximum IT of 60 seconds. The burnings that exceeded this time were classified as 
"negative burning" and received standardized values: IT equal to 61 seconds; TC equal zero seconds and $\mathrm{FH}$ equal zero centimeters.

The flammability index (FI) of the selected species was obtained according to the IF and IT, varying as follow: $0=$ very low flammable; $1=$ low flammable; $2=$ moderately flammable; $3=$ flammable; 4 $=$ very flammable; and $5=$ extremely flammable $($ Table 1$)$.

Table 1 - Classification of flammability according to the ignition time (IT), in seconds, and ignition frequency (IF), in percentage

\begin{tabular}{c|c|c|c|c|c|c}
\hline \multirow{2}{*}{ IT (s) } & \multicolumn{6}{|c}{ IF $(\%)$} \\
\cline { 2 - 6 } & $\leq 50$ & $50-79$ & $80-84$ & $85-89$ & $90-94$ & $>94$ \\
\hline$>32.5$ & 0 & 0 & 0 & 1 & 1 & 2 \\
$27.6-32.5$ & 0 & 0 & 1 & 1 & 2 & 2 \\
$17.6-27.5$ & 0 & 0 & 1 & 2 & 2 & 2 \\
$12.6-17.5$ & 1 & 1 & 2 & 2 & 3 & 3 \\
$<12.6$ & 1 & 1 & 2 & 3 & 3 & 4 \\
\hline
\end{tabular}

\subsection{Combustibility test}

The fire behavior was measured according to the methodology presented by Batista and Biondi (2009). For each evaluated species, 10 repetitions of experimental burnings were carried out in $1 \mathrm{~m}^{2}$ plots with a load of $1 \mathrm{~kg}$ of fine dry fuel material $(<0.7 \mathrm{~cm}$ in diameter), as presented in Figure 2 . The experimental burnings were filmed for later data collection.

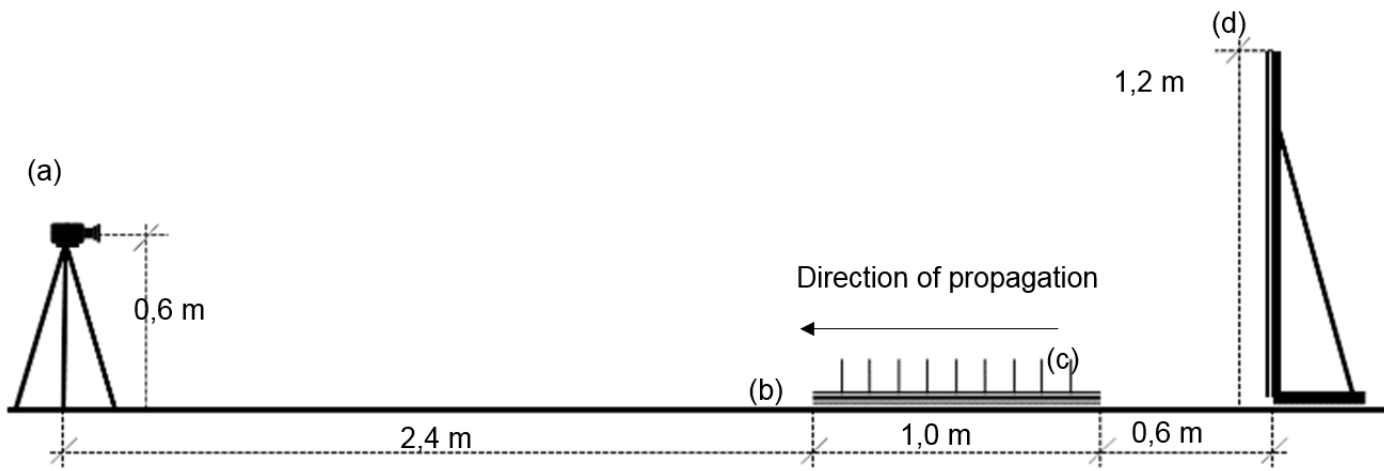

Figure 2 - Schematic illustration of components.

Note: (a) camera; (b) plot with fuel material; (c) ruler for speed of fire propagation determination; (d) panel for reading the flame height.

The following fire behavior parameters were analyzed: flame height, speed of propagation, residual material, fire intensity and lower calorific value, described below:

i. $\quad$ Flame length (FL), in centimeters: is obtained every $10 \mathrm{~cm}$ of fire propagation, having as reference a graduated rule. Eight observations are made per experimental burning. Subsequently, this variable was corrected as a function of the fire position in the plot and the flame height. For this, the following correction formulas were used:

For flame length greater than $60 \mathrm{~cm}$ (Equation 1):

$$
\mathrm{Cf}=-(\mathrm{D}+60) *\left[\frac{(\mathrm{FLv}-60)}{400}\right]
$$


For flame length less than $60 \mathrm{~cm}$ (Equation 2):

$$
\mathrm{Cf}=+(\mathrm{D}+60) *\left[\frac{(60-\mathrm{FLv})}{400}\right]
$$

where: $\mathrm{Cf}=$ correction factor, in $\mathrm{cm} ; \mathrm{D}=$ distance of the flame in relation to the beginning of the burn, in $\mathrm{cm} ; \mathrm{FLv}=$ flame length shown in the video, in $\mathrm{cm}$.

ii. Speed of propagation $(\mathrm{Sp})$, in $\mathrm{cm} \cdot \mathrm{s}^{-1}$ : determined by the relation between preestablished distances and the time spent by the fire front line to travel through them. For each experimental burning, eight observations were obtained.

iii. Residual material $(\mathrm{Rm})$, in $\mathrm{g} \cdot \mathrm{m}^{-2}$ : collected in the central area of the burning plot, using a template of $400 \mathrm{~cm}^{2}(20 \times 20 \mathrm{~cm})$.

iv. Fire intensity (I), in kcal. $\mathrm{m}^{-1} \cdot \mathrm{s}^{-1}$ : obtained by the formula of Byram (1959) (Equation 3).

$$
I=H \cdot w \cdot r
$$

where: $\mathrm{I}=$ fire intensity, in $\mathrm{kcal} . \mathrm{m}^{-1} \cdot \mathrm{s}^{-1} ; \mathrm{H}=$ calorific value, in $\mathrm{kcal} \cdot \mathrm{kg}^{-1} ; \mathrm{w}=$ mass of available fuel material per area, in $\mathrm{kg} . \mathrm{m}^{-2} ; \mathrm{r}=$ speed of fire propagation, in $\mathrm{m} \cdot \mathrm{s}^{-1}$.

v. Lower calorific value (LCV), in $\mathrm{kcal}^{\mathrm{kg}}{ }^{-1}$ : determined with an isoperibol calorimeter, following the standard of ABNT (1984) NBR 8633.

\subsection{Data analysis}

The parameters of flammability: ignition frequency (IF), ignition time (IT), time of complete combustion (TC) and flame height (FH); and combustibility: flame length (FL), speed of propagation (Sp), residual material $(\mathrm{Rm})$ and lower calorific value (LCV), were submitted to cluster analysis.

\section{Results}

In Table 2 are presented the parameters of flammability and combustibility and Figure 3 shows the cluster analysis of the studied species.

\begin{tabular}{|c|c|c|c|c|c|c|c|c|c|c|}
\hline \multirow{2}{*}{ Species } & \multicolumn{4}{|c|}{ Flammability } & \multirow{2}{*}{ FI } & \multicolumn{4}{|c|}{ Combustibility } & \multirow{2}{*}{ Intensity } \\
\hline & IF & IT & TC & FH & & FL & Sp & $\mathbf{R m}$ & LCV & \\
\hline Schinus terebinthifolius & 14 & 58.4 & 9.6 & 11.9 & $\mathbf{0}$ & 1.7 & 1.6 & 1445.9 & 4037.3 & 1.1 \\
\hline Bougainvillea glabra & 10 & 59.7 & 7.0 & 16.8 & $\mathbf{0}$ & 11.0 & 10.7 & 1643.8 & 3489.9 & 6.2 \\
\hline Michelia champaca & 86 & 19.8 & 4.5 & 9.2 & $\mathbf{1}$ & 32.6 & 70.0 & 219.0 & 3707.8 & 43.3 \\
\hline Viburnum odoratissimum & 88 & 23.3 & 5.4 & 11.9 & 1 & 32.1 & 48.8 & 200.9 & 3877.9 & 31.5 \\
\hline Rhododendron simsii & 98 & 18.8 & 26.9 & 8.6 & 2 & 24.4 & 15.6 & 290.0 & 4454.5 & 11.6 \\
\hline Casearia sylvestris & 96 & 17.5 & 5.5 & 13.7 & 3 & 23.3 & 32.4 & 395.7 & 4449.4 & 24.0 \\
\hline Pinus taeda & 100 & 16.3 & 12.5 & 12.1 & 3 & 36.6 & 55.8 & 176.6 & 4701.0 & 43.8 \\
\hline Magnolia grandifolia & 100 & 12.5 & 7.4 & 25.2 & 4 & 40.0 & 44.5 & 138.0 & 4259.3 & 31.6 \\
\hline Jasminym mesnyi & 100 & 10.9 & 18.5 & 13.9 & 4 & 14.3 & 27.1 & 440.1 & 4438.3 & 20.0 \\
\hline
\end{tabular}

Table 2 - Values of flammability and combustibility parameters of the tested species

Note: $F I=$ Flammability index; $0=$ very low flammable; $1=$ low flammable; $2=$ moderately flammable $; 3=$ flammable; 4 = very flammable; and 5 = extremely flammable.

S. terebinthifolius and B. glabra were classified as very low flammable (FI $=0)$, with an IT superior to that found by Molina et al. (2017) for species with low flammability in Spain. Kovalsyki et al. (2016), while studying the flammability of the same species, stated that both have shorter TC and $\mathrm{FH}, 1.3 \mathrm{~s}$ and $1.7 \mathrm{~cm}$ for S. terebinthifolius and $0.7 \mathrm{~s}$ and $1.2 \mathrm{~cm}$ for B. glabra, than what was found in the present study. 


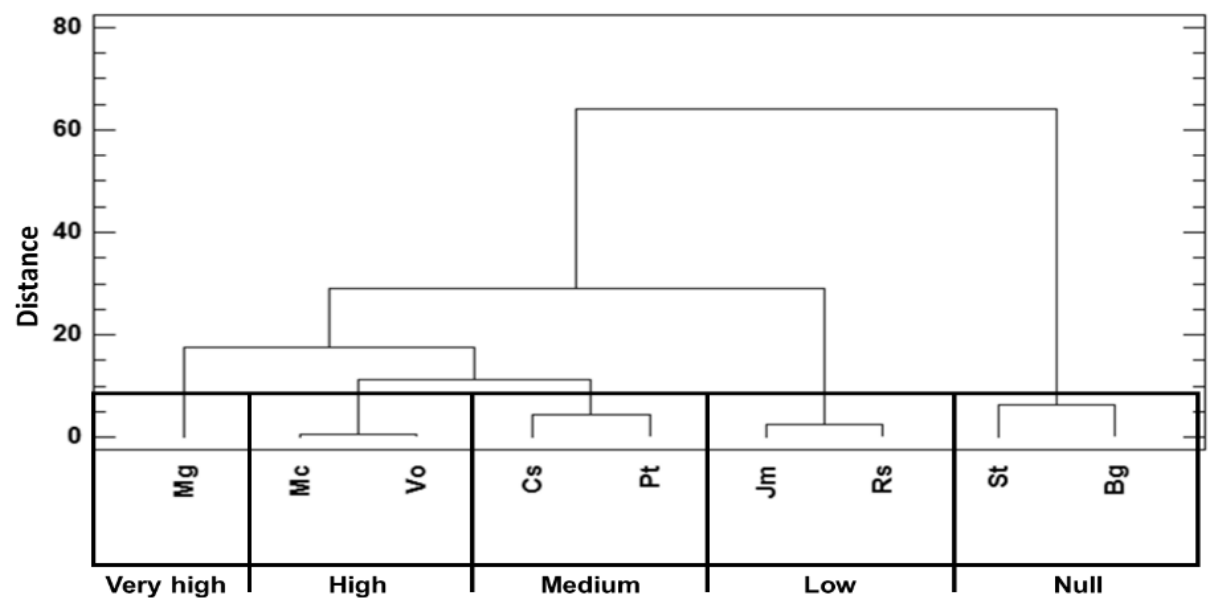

Figure 3 - Dendrogram according to the species flammability and combustibility

Another factor that favored the classification of B. glabra in class zero was a moisture content of $210.6 \%$ for this specie. The greater the moisture content, the greater the difficulty of material to ignite, where a high energy expenditure will be required to start the combustion process (White 2018).

Although S. terebinthfolius had a lower moisture content (142.4\%) and higher flammability compared to other species tested in this study, such as V. odoratissimum (163.1\%) and M. champaca (147.6\%), this species can be used as fuel breaks. Due to its low combustibility, S. terebinthfolius represents a small chance of the fire to escape control, allowing the combat in safety (Soares et al. 2017).

$J$. mesnyi has low combustibility, however is very flammable, not being indicated to act as fuel break. Even being classified as moderately flammable, $R$. simsii ignition frequency and time of complete combustion show a greater capacity to ignite and keep the flames than those species with low flammability and combustibility. Even though the heat fluxes measured during forest fires have a magnitude greater than the heat sources used in laboratory studies, it is known that ignition sources (cigarettes, bonfires, sparks, etc.) do not need to have large heat fluxes (Fernandes and Cruz. 2012).

$M$. gradiflora, even with some parameters lower than those found for $P$. taeda, has the lowest IT and combustibility, but was characterized as very flammable, not being recommended for use as fuel breaks. Results found by Mola et al. (2014) indicated that the susceptibility and severity of fires in the Apalachicola Ravines, Florida - USA were higher after the increase in the number of individuals of $M$. grandiflora.

\section{Conclusion}

The cluster analysis showed to be effective in the classification of species according to their flammability and combustibility. S. terebinthfolius, B. glabra and $R$. simsii are the species indicated for use as fuel breaks.

\section{References}

ABNT (1984) Determinação do poder calorífico - Método de ensaio. NBR 8633 (Associação Brasileira Normas Técnicas: Brasília, DF).

Batista AC, Biondi D (2009) Avaliação da inflamabilidade de Ligustrum licidum Aiton (Oleaceae) para uso potencial em cortinas de segurança na região sul do Brasil. Revista Brasileira de Ciências Agrárias 4, 435-439. 
Byram GM (1959). Combustion of forest fuels. In 'Forest Fire: Control and Use'. (Ed. KP Davis) pp. 77-84. (McGraw-Hill: New York)

Castillo MS, Correa LJ (2012) Acciones para la disminución del peligro de incendios forestales en áreas de interfaz urbanoforestal - estudio de caso. Territorium 19, 95-100.

Castillo MS, Julio GA, Quintanilla VP (2011) Vulnerabilidad y daño potencial ocasionado por incendios en áreas de interfaz urbano-forestal, provincia de Valparaíso. Chile central. Territorium 18, 247-254.

Fernandes PM, Cruz, MG (2012) Plant flammability experiments offer limited insight into vegetationfire dynamics interactions. New Phytologist 194, 606-609.

Ganteaume A, Jappiot M, Lampin C, Guijarro M, Hernando C (2013) Flammability of Some Ornamental Species in Wildland-Urban Interfaces in Southeastern France: Laboratory Assessment at Particle Level. Environmental Management 52, 467-480.

Haltenhoff, H (2006) 'Silvicultura preventiva.' (Ministerio de agricultura: Santiago)

Kovalsyki B, Takashina IK, Tres A, Tetto AF, Batista AC (2016) Inflamabilidade de espécies arbóreas para uso em cortina de segurança na prevenção de incêndios florestais. Pesquisa Florestal Brasileira 88, 387-391.

Long-Fournel M, Morge D, Bouillom C, Jappiot M (2013) La cartographie des interfaces habitat-forêt : un outil de diagnostic territorial dans la prévention du risque d'incendie de forêt dans le Sud de la France. Sciences Eaux and Territoires: la Revue du IRSTEA, 1-8.

Meldrum JR, Champ PA, Brenkert-Smith H, Warziniack T, Barth CM, Falk LC (2015) Understanding Gaps Between the Risk Perceptions of Wildland-Urban Interface (WUI) Residents and Wildfire Professionals. Risk analysis 9, 1-25.

Mell EW, Manzello SL, Maranghides A, Butry D, Rehm RG (2010) The wildland-urban interface fire problem - current approaches and research needs. International Journal of Wildland Fire 19, 238251.

Mola JM, Varner JM, Jules ES, Spector T (2014) Altered Community Flammability in Florida's Apalachicola Ravines and Implications for the Persistence of the Endangered Conifer Torreya taxifolia. Plos one 8, 1-8.

Molina JR, Martín T, Silva FR, Herrera MA (2017) The ignition index based on flammability of vegetation improves planning in the wildland-urban interface: A case study in Southern Spain. Landscape and urban planning 158, 129-138.

Montagné-Huck C, Brunette M (2018) Economic analysis of natural forest disturbances: A century of research. Journal of Forest Economics 32, 42-71.

Petriccione M (2006) 'Infiammabilità della lettiera di diverse specie vegetali di ambiente Mediterraneo.' (Università Degli Studi Di Napoli Federico II: Napoli)

Soares RV, Batista AC, Tetto AF (2017) 'Incêndios florestais: controle, efeitos e uso do fogo.' (UFPR: Curitiba)

Syphard AD, Massada AB, Butsic V, Keeley JE (2013) Land Use Planning and Wildfire: Development Policies Influence Future Probability of Housing Loss. Plos one 8, 1-12.

Valette JC (1990) lnflammabilités des espèces forestières méditerranénnes: conséquences sur la combustibilité des formations forestières (Mediterranean Forest Species Flammability, Consequences on Forest Communities Combustibility) Revue Forestière Française 42, 76-92.

White BLA (2018) Modelos matemáticos de previsão do teor de midade dos materiais combustíveis florestais finos e mortos. Ciência florestal 28, 432-445. 